\title{
Rancang Bangun Cloud Storage Pada Ubuntu 16.04 Menggunakan Layanan Nextcloud Di SMK Texmaco Pemalang
}

\author{
Nanda Fergiawan Santoso \\ Program Studi Informatika Universitas Muhammadiyah Surakarta (UMS) Surakarta, Indonesia \\ Nanda.fergiawan@gmail.com \\ Heru Supriyono \\ Program Studi Informatika Universitas Muhammadiyah Surakarta (UMS) Surakarta, Indonesia \\ Heru.supriyono@ums.ac.id
}

\begin{abstract}
Abstraksi- Penerapan teknologi informasi cloud computing dalam dunia pendidikan saat ini akan sangat bermanfaat mengingat banyak file yang akan didokumentasikan dan banyaknya keuntungan yang ditawarkan. Cloud computing merupakan sebuah layanan yang dapat dikonfigurasi dan digunakan untuk berbagi sumber daya secara bersama - sama dimana saja dan kapan saja. Teknologi cloud computing ini dapat dijadikan pengganti penggunaan media penyimpanan statis yang masih memiliki kekurangan. Kekurangan yang masih melekat pada media penyimpanan statis ini antara lainseperti kapasitas yang terbatas, rawan terinfeksi virus, mudah hilang dan rusak.Tujuan dari penelitian ini adalah menerapkan sebuah cloud storage menggunakan layanan nextcloud. Metode yang dipakai dalam membuat cloud storage ini meliputi analisis kebutuhan akan sistem, kebutuhan software dan hardware,instalasi sistem,konfigurasi,implementasi dan uji tes. Software yang digunakan sebagai sistem operasi adalah ubuntu 16.0464 bit dan nextcloud sebagai software utama cloud storage. Hardware yang digunakan sebagai server adalah laptop HP N216-TU dengan spesifikasi : intel corei3, ram 4GB, hardisk 60GB. Hasil dari penelitian ini adalah sistem cloud storage yang sudah di implementasikan disekolah dapat diakses baik dijaringan lokal maupun dari luar jaringan sekolah secara online. Pengguna dapat melakukan upload,download,sharing file, edit file secara synchronizing dan service SSH untuk admin yang ingin meremote server dari luar jaringan. Dari perancangan cloud storage ini menghasilkan max upload $817 \mathrm{Kbps}$, min $80 \mathrm{Kbps}$ dan average 249 Kbps. Dan max download 150 Kbps, min 80 Kbps, dan average 130 Kbps.
\end{abstract}

Katakunci-Cloud computing; cloud storage; Nextcloud; SSH; upload; download;

\section{Pendahuluan (Heading 1)}

Pada SMK Texmaco Pemalang sebernarnya telah mempunyai sumber daya yang mumpuni dalam hal komputerisasi. SMK Texmaco Pemalang memiliki 1516 siswa, guru serta karyawan 90 orang dan memiliki 6 buah jurusan. Pada kegiatan sehari - hari seperti guru input nilai siswa, mengolah administrasi sekolah, merekap laporan hasil kegiatan ekstrakulikuler misalnya foto dan video masih menggunakan media penyimpanan yang bersifat statis untuk file soft copy dan laporan berupa hard copy. Media penyimpanan statis ini memiliki kekurangan seperti kapasitas yang terbatas, mudah rusak, rawan terinfeksi virus dan hilang.

Pada permasalahan diatas maka dirancanglah sebuah penyimpanan data terpusat menggunakan layanan nextcloud yang dapat melakukan olah file dokumen secara synchronizing pada komputer pengguna saat sudah terhubung dengan server cloud storage dan dapat diakses secara online diluar jaringan sekolah maupun offline melalui jaringan lokal di SMK Texmaco Pemalang. Nextcloud merupakan sebuah layanan opensource yang dapat digunakan sebagai 
sebuah layanan cloud storage. Pemilihan nextcloud sebagai software utama dalam cloud storage karena memiliki sebuah user interface yang mudah untuk digunakan, memiliki banyak fitur support plugin aplikasi, memiliki aplikasi monitor penggunaan server, mudah melakukan dalam konfigurasi

\section{DASAR TEORI DAN TINJAUAN PUSTAKa}

Pada kehidupan sehari - hari, penerapan dari cloud computing sudah pasti digunakan oleh khalayak umum seperti sharing file, download, upload dan akses media sosial. Cloud Computing merupakan sebuah media yang memungkinkan penggunaan sumber daya secara bersama - sama yang mudah diakses dimana saja, dapat dikonfigurasi, dan layanan yang dapat digunakan sesuai dengan kebutuhan [1].

Pada perancangan Cloud storage ini menggunakan layanan dari nextcloud yang masuk dalam kategori Infrastructure as a Service (IaaS) dalam dunia cloud computing. IaaS sendiri merupakan sebuah layanan yang menyediakan sumber daya informasi, media penyimpanan,processing power, memory dan sistem operasi [2]

Pada model IaaS banyak digunakan untuk membuat sebuah layanan cloud storage karena akses file yang dapat dilakukan secara online. IaaS merupakan model layanan yang dapat mengakses server virtual dalam waktu yang cepat [3]. Cloud Storage merupakan sebuah media penyimpanan awan secara online dimana file akan disimpan pada server virtual dan konfigurasinya dapat disesuaikan kebutuhan pengguna [4].

Pada pendistribusian system cloud storage terdapat dua acara yaitu, client/server system dan peer to peer system [5]. Distribusi data pada cloud storage yang terjadi pada saat client mulai mengakses sebuah file pada server tentu perlu diperhatikan kemanan datanya. Aspek yang akan menjadi perhatian dalam mengamankan data pada cloud storage yaitu transmisi dari klien ke sever cloud, dari server cloud ke klient dan data pribadi client [6].
Sebuah cloud Storage dapat dikatakan aman apabila sudah terdapat beberapa hal seperti (Cofidenttiality) mampu menjaga kerahasiaan data dan informasi, (integrity) data tidak akan berubah tanpa seijin pihak yang berwenang, (availability) informasi dapat diakses kapan saja dan dimana saja saat informasi itu dibutuhkan [7].

\section{Metode Penelitian}

Perancangan cloud storage ini peniliti telah melalui beberapa metode seperti analisis kebutuhan akan sistem, anailisis kebutuhan software dan hardware, instalasi serta konfigurasi sistem, implementasi dan uji tes.

\section{A. Analisa kebutuhan akan sistem}

Pada tahap ini peneliti melakukan berbagai analisa kebutuhan untuk melakukan penelitian sebagai pendukung dalam perancangan sistem. Kebutuhan perangkat keras yaitu laptop dengan processor intel core i3, Memory 4GB, HDD 500GB, mikrotik 1100AHX, Modem dan kabel UTP. kebutuhan perangkat lunak yaitu Sistem Operasi Ubuntu 16.04, paket PHP7, Apache2, Mysql-Server , SSH, fail2ban, OpenSSL dan nextcloud.

\section{B. Pengumpulan data}

Mengumpulkan berbagai informasi yang diperoleh sebagai bahan acuan dan penunjang dalam merancang cloud storage di SMK Texmaco Pemalang. Pada tahap ini, peneliti membagi menjadi beberapa tahap, yaitu :

1) Studi Pustaka, mengumpulkan berbagai teori-teori yang terkait dengan penelitian sebagai pedoman yang terkumpul dari beberapa buku dan jurnal. Hal ini bertujuan untuk memperkuat penelitian karena memiliki referensi penelitian terdahulu melalui jurnal penelitian.

2) Observasi, melakukan pengamatan mengenai objek-objek secara langsung untuk mengetahui informasi untuk merancang sistem.

3) Wawancara, mengumpulkan informasi tentang objek penelitian dengan bertanya langsung dengan pihak terkait yaitu 
kaprodi jurusan Teknik jaringan dan komuter dan IT support di SMK Texmaco Pemalang.

\section{Arsitektur Cloud Storage}

Perancangan desain arstitektur ini menggambarkan bagaimana sistem kan berinteraksi dengan setiap pengguna yang akan menggunakan cloud storage. Pengguna di SMK Texmaco Pemalang dapat mengakses cloud storage ini baik didalam jaringan sekolah maupun diliuar sekolah. Khusus

untuk admin yang akan meremote server diluar sekolah sudah disediakan service SSH. arsitektur cloud storage pada SMK Texmaco Pemalang dapat dilihat pada gambar 1 sebagai berikut.

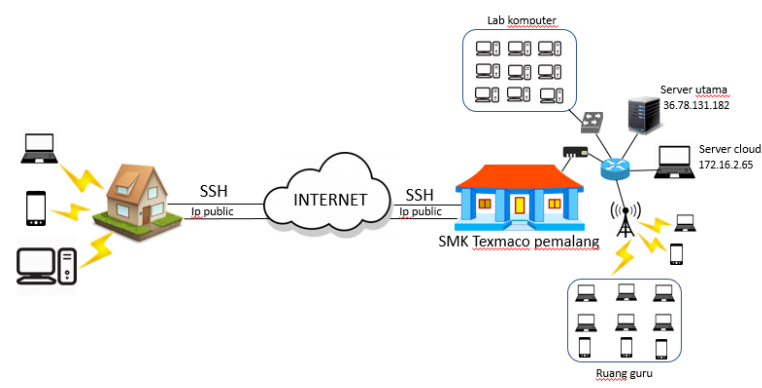

Gambar 1. Arsitektur cloud storage

\section{Implementasi Sistem}

1. Konfigurasi port pada Mikrotik

Tahap dimana membuka dua port pada Mikrotik, yaitu port 5443 untuk web server dan port 1996 untuk service SSH.

a. Membuka port 5443

Konfigurasi pada Mikrotik yang dilakukan adalah pada form Chain pilih dstnat, mengisi alamat ip address DNS server pada kolom Dst Address dan Dst port 5443. Konfigurasi port 5443 dapat dilihat pada gambar 2.

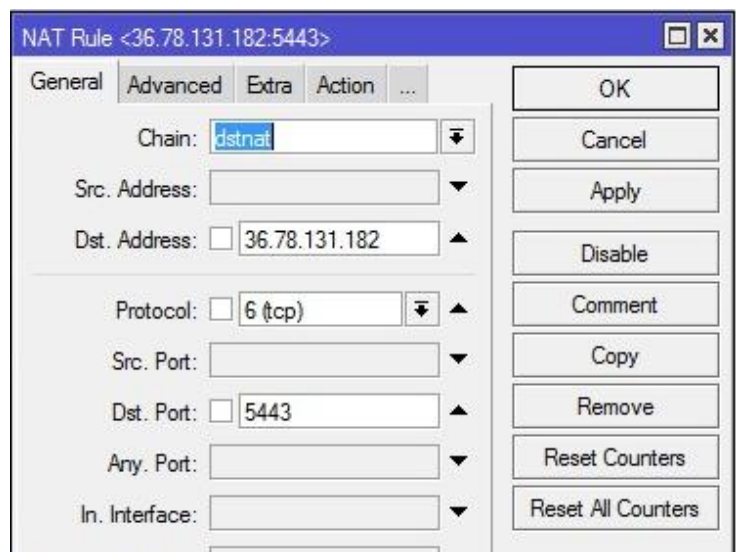

Gambar 2. Membuka port 5443

Langkah berikutnya adalah konfigurasi yang akan mengarah ke server cloud storage. Masuk pada kolom action, isi scroll button action, to address dengan alamat IP server cloud storage, dan To ports yang mengarah ke ports webserver di cloud storage. Konfigurasi yang mengarah ke server cloud storage dapat dilihat pada gambar 3 sebagai berikut.

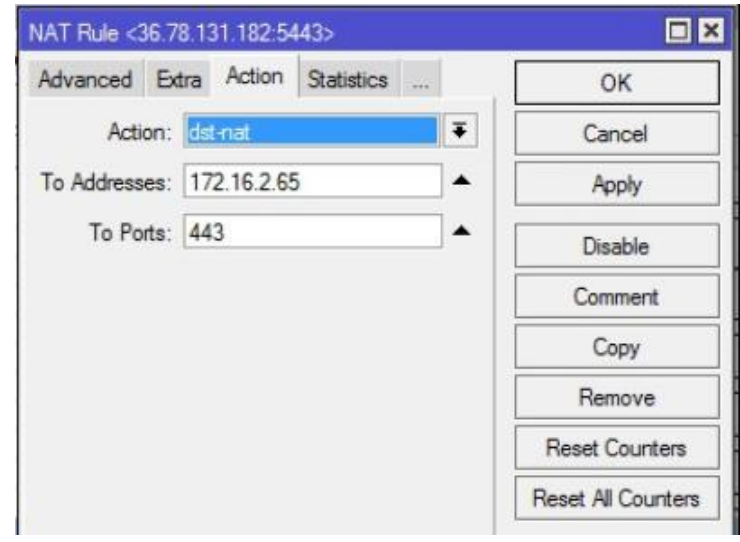

Gambar 3. Konfigurasi ke server cloud storage

b. Membuka port 1996

Konfigurasi pada Mikrotik yang dilakukan adalah pada form Chain pilih dstnat, mengisi alamat ip address DNS server pada kolom Dst Address dan Dst port 5443. Konfigurasi port 5443 dapat dilihat pada gambar 4 . 


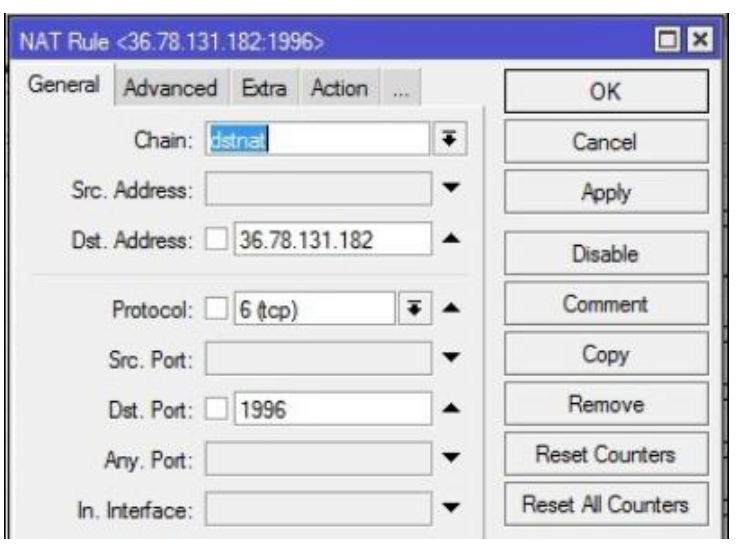

Gambar 4. Konfigurasi ke DNS server

Langkah berikutnya adalah konfigurasi yang akan mengarah ke server cloud storage. Masuk pada kolom action, isi scroll button action, to address dengan alamat IP server cloud storage, dan To ports yang mengarah ke ports webserver di cloud storage. Konfigurasi yang mengarah ke server cloud storage dapat dilihat pada gambar 5 sebagai berikut.

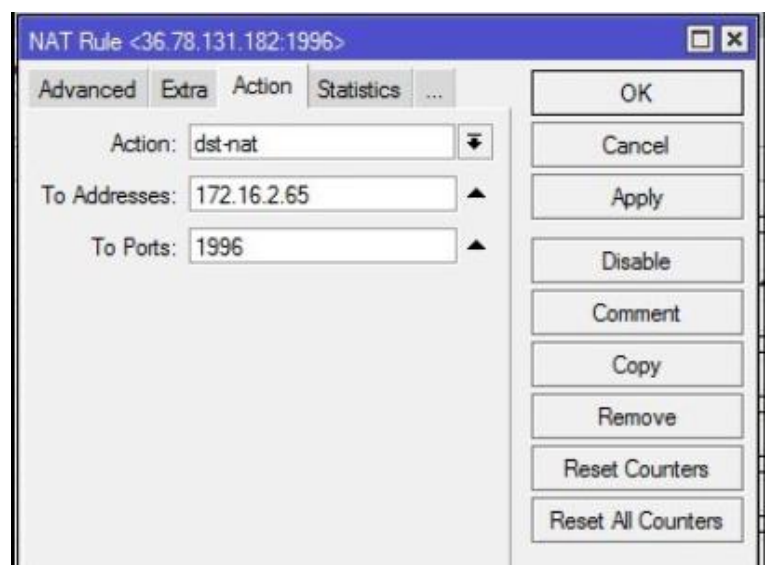

Gambar 5. Konfigurasi ke server cloud storage

2. Instalasi sistem operasi Ubuntu 16.04

Sistem operasi Ubuntu 16.04 digunakan sebagai tempat untuk di installnya paket paket pendukudung dan nextcloud sebagai software utama pada cloud storage. operating system Ubuntu 16.04 di install menggunakan media flashdisk dan dalam pembuatan bootable operating system tersebut menggunakan software Rufus 2.11. Kemudian pada server cloud storage diatur booting pertama adalah dari flashdisk dan tinggal mengikuti langkah selanjutnya

3. Instalasi paket pendukung cloud storage
Paket pendukung ini diperlukan agar cloud storage dapat berjalan dengan baik pada sistem operasi ubuntu 16.04 yang telah di install. Instalasi paket yang diperlukan berupa penambahan repository pada server cloud storage, instalasi apache 2 web server, instalasi PHP7, instalasi Mysql Server, instalasi OpenSSL, instalasi OpenSSH, Instalasi fail2ban.

\section{Instalasi nextcloud}

Instalasi nextcloud ini diperlukan karena nextcloud sendiri adalah software utama yang akan dijadikan sebagai wadah dari cloud storage itu senditi. Instalasi nextcloud dilakukan dengan cara mendownload terlebih dahulu dari website resmi nextcloud. Kemudian di ekstrak dan diletakan pada folder /var/www/nextcloud. Selanjutnya mengkonfigurasi file 000-default.conf pada webserver agar letak documentRoot berada pada folder /var/www/nextcloud. Tahap selanjutnya adalah mengisikian username, password, nama database untuk nextcloud yang telah dibuat pada saat nextcloud diakses pertama kali memakai browser.

Tahap selanjutnya adalah melakukan konfigurasi pada file config.conf agar server cloud storage dapat terhubung pada server utama. konfigurasi pada server cloud storage dapat dilihat pada gambar 6 seperti berikut.

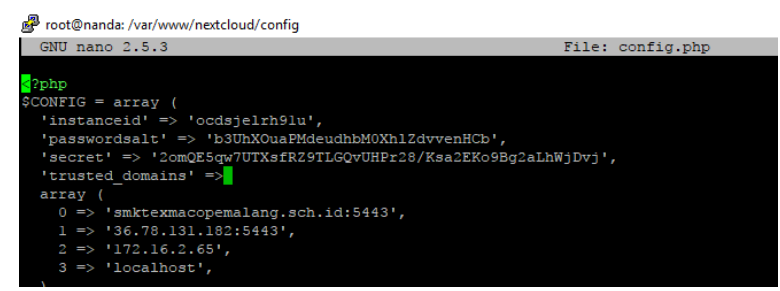

Gambar 6. Konfigurasi pada file config.conf

Setelah melakukan konfigurasi pada file config.conf Login nextcloud ini sudah dapat diakses melalui web browser maupun aplikasi dari nextcloud sendiri dengan mengisi URL pada address bar https://smktexmacopemalang.sch.id:5443.

Pada halaman login sendiri sudah mengalami perubahan ikon dari default nextcloud menjadi ikon SMK Texmaco Pemalang Tampilan login web server dapat dilihat pada gambar 7 dan login aplikasi nextcloud gambar 8 . 


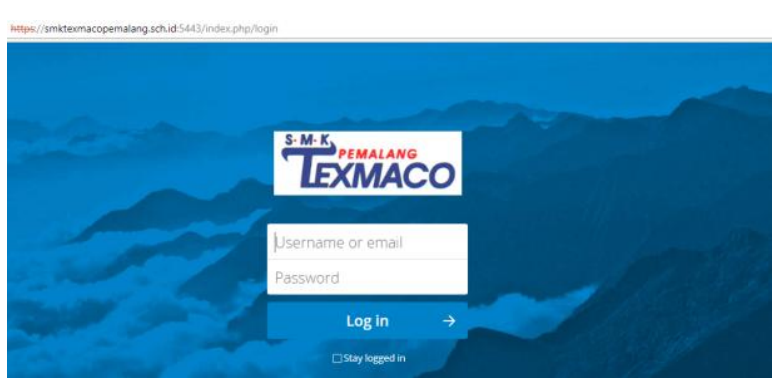

Gambar 7. Halaman login web server cloud storage

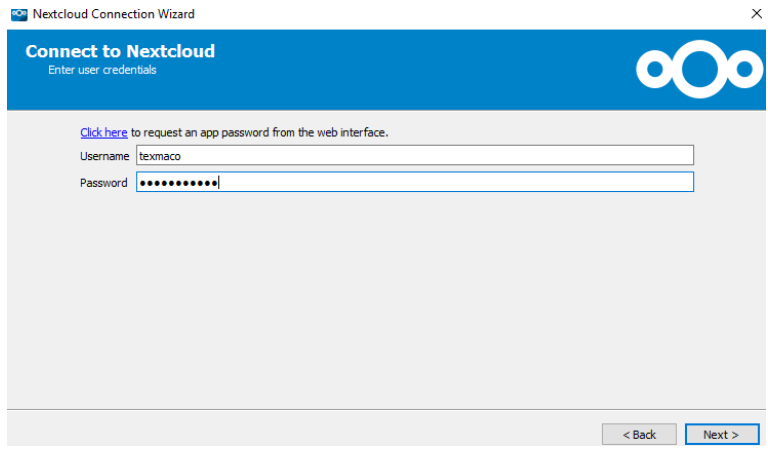

Gambar 8. Halaman login aplikasi nextcloud

\section{HASIL DAN PEMBAHASAN}

Pada tahap ini jaringan pada SMK Temaco Pemalang akan dilakukan pengujian terhadap sistem cloud storage yang telah dibuat. Pengujian terhadap jaringan komputer meliputi ketahanan server, stabililitas koneksi internet, kemanan server cloud storage dan pengujian beberapa aplikasi pada sistem cloud storage yang dilakukan oleh ketua prodi jurusan teknik komputer dan jaringan. Pengujian adalah pengujian terhadap kesiapan sistem cloud storage pada saat digunakan dalam menjalankan segala fitur dan fungsinya.

Pengujian pertama yang dilakukan adalah uji upload dan download. Pada pengujian kali ini menggunakan jaringan wifi pada modem mifi andromax $\mathrm{m} 3 \mathrm{z}$ dan menghasilkan data seperti pada tabel 1 .

Tabel 1. Tes upload dan download speed

\begin{tabular}{|c|c|c|c|c|}
\hline No & Tes & $\begin{array}{c}\text { Maximal } \\
\text { speed }\end{array}$ & $\begin{array}{c}\text { Minimum } \\
\text { speed }\end{array}$ & Average \\
\hline 1 & upload & $817 \mathrm{Kbps}$ & $80 \mathrm{Kbps}$ & $249 \mathrm{Kbps}$ \\
\hline 2 & download & $150 \mathrm{Kbps}$ & $80 \mathrm{Kbps}$ & $130 \mathrm{Kbps}$ \\
\hline
\end{tabular}

Hasil yang tertera pada tabel 1 didapatkan dari percobaan test upload dan download yang dapat dilihat pada gambar 9 (a) upload dan (b) download.

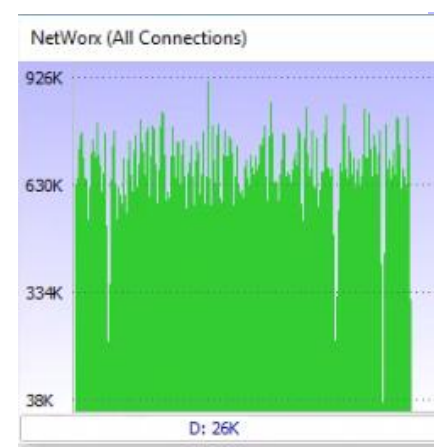

(a) upload

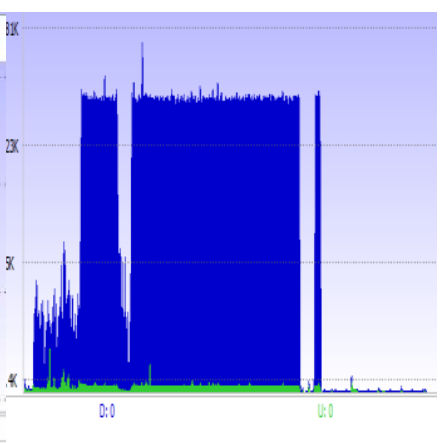

(b) download
Gambar 9. upload dan download

Tes selanjutnya adalah tes keamanan komunikasi jaringan pada server cloud storage menggunakan software wireshark. Wireshark sendiri merupakan software yang digunakan untuk menscanning paket - paket yang ada dalam jaringan internet dan digunakan untuk menganalisa keamanan jaringan yang ada. Pada pengujian tes kemanan komunikasi jaringan di server cloud storage ini tidak ditemukannya paket HTTPs sebagai jalur komunikasi web server, yang menandakan bahwa konfigurasi SSL yang dilakukan telah berhasil mengenkripsi paket data pada port 5443 yang digunakan sebagi port web server. Hasil scan menggunakan wireshark dapat dilihat pada gambar 15 .

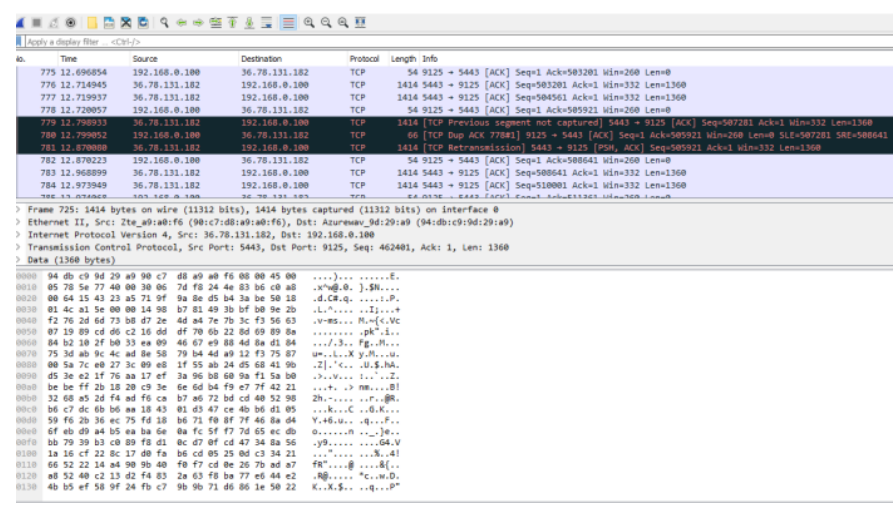

Gambar 10. Hasil scan wireshark

Hasil pengujian service SSH menggunakan software putty yang sudah berhasil login kedalam sistem dapat dilihat pada gambar 11 dan gambar 12 sebagai berikut. 


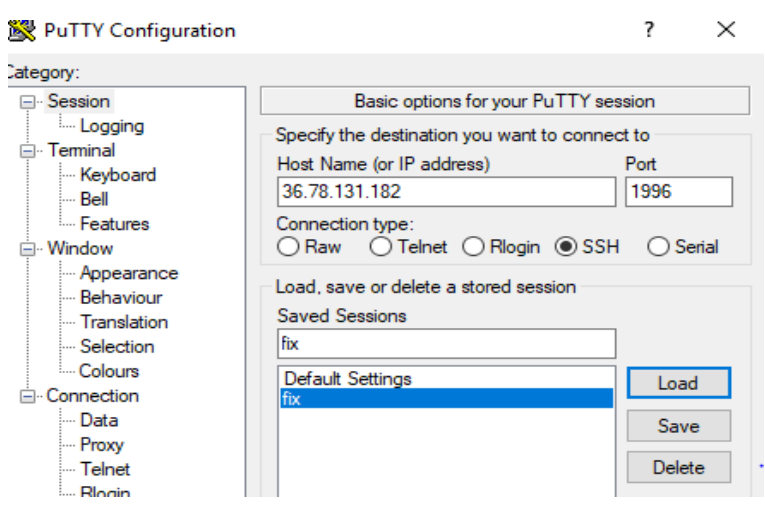

Gambar 11. Software putty

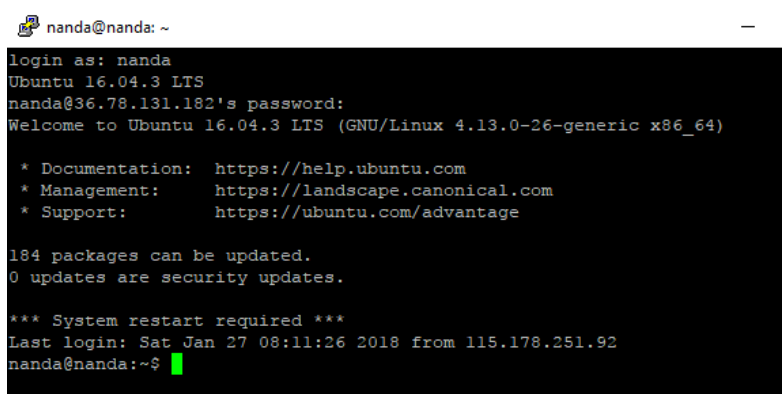

Gambar 12. Login service SSH

Pengujian berikutnya dari server utama nextcloud menggunakan aplikasi Nmap dan aplikasi scan security dari nextcloud. Pengujian ini dilakukan menggunakan jaringan internet pada SMK Texmaco Pemalang. Pada hasil pengujian dapat dilihat pada tabel 2 menggunakan software Nmap dan gambar 16 menggunakan layanan nextcloud security.

Tabel 2. Hasil Scan dari Nmap

\begin{tabular}{|c|c|c|c|c|}
\hline No & $\begin{array}{c}\text { Nama } \\
\text { service }\end{array}$ & $\begin{array}{c}\text { No. } \\
\text { Port }\end{array}$ & Rentan & Keterangan \\
\hline 1 & Apache2 & $\begin{array}{c}80, \\
443\end{array}$ & - & \\
\hline 2 & SSH & 1996 & $\mathrm{v}$ & $\begin{array}{c}\text { Dicegah } \\
\text { dengan } \\
\text { software } \\
\text { fail2ban }\end{array}$ \\
\hline 3 & SSL & 5443 & - & \\
\hline
\end{tabular}

Dari pengujian pada tabel 2 menggunakan Nmap dapat diketahui bahwa dari semua port yang terbuka hanya satu service yang masih rentan disusupi oleh hacker yaitu SSH. Untuk menanggulangi masalah tersebut digunakanlah software fail2ban yang bertugas untuk membatasi jumlah login yang gagal pada saat masuk kedalam service SSH dan memblokir akses SSH apabila sudah melakukan banyak kegagalan pada saat login.

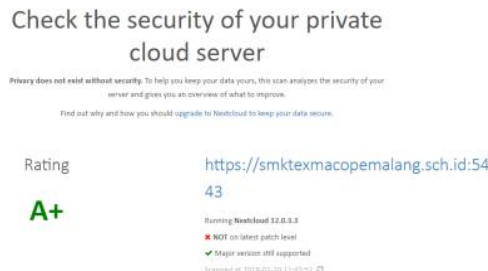

Gambar 11. Hasil scan nextcloud security

Pengujian dari gambar 11, menunjukan bahwa keamanan cloud storage dalam mengamankan data mendapatkan hasil rating A+. Dengan hasil pengujian yang telah dilakukan tersebut seharusnya sudah mampu mengamankan data pengguna di SMK Texmaco Pemalang dalam pengoperasian cloud storage pada setiap kegiatan di sekolah.

Pengujian berikutnya adalah pengujian yang dilakukan oleh kaprodi jurusan Teknik komputer dan jaringan saat melakukan testing yang dilakukan disekolah. Pengujian yang dilakukan oleh kaprodi teknik jaringan dan komputer dapat dilihat pada tabel 3.

Tabel 3. Pengujian yang dilakukan oleh guru dan kaprodi

\begin{tabular}{|c|c|c|}
\hline No & Pengujian yang dilakukan & $\begin{array}{c}\text { Hasil } \\
\text { tes }\end{array}$ \\
\hline 1 & Menyimpan file & $\mathrm{v}$ \\
\hline 2 & Sharing file & $\mathrm{V}$ \\
\hline 3 & Membuat file txt & $\mathrm{V}$ \\
\hline 4 & Membuka file pdf & $\mathrm{V}$ \\
\hline 5 & Membuka video & $\mathrm{V}$ \\
\hline 6 & Membuka musik & $\mathrm{V}$ \\
\hline 7 & Membuat akun $u s e r$ & $\mathrm{~V}$ \\
\hline 8 & $\begin{array}{l}\text { Memberikan } \\
\text { aplikasi untuk } \text { user }\end{array}$ & $\mathrm{v}$ \\
\hline 9 & $\begin{array}{lr}\text { Memberikan } & \text { batasan } \\
\text { kapasitas } & \text { media } \\
\text { penyimpanan pada } & \text { user }\end{array}$ & $\mathrm{V}$ \\
\hline 10 & synchronizing file dan folder & $\mathrm{V}$ \\
\hline
\end{tabular}

Untuk perkuat pernyataan pada table 3 diatas, pengujian yang dilakukan oleh prodi jurusan Teknik komputer dan jaringan di SMK Texmaco Pemalang dapat dilihat pada gambar sebagai berikut 


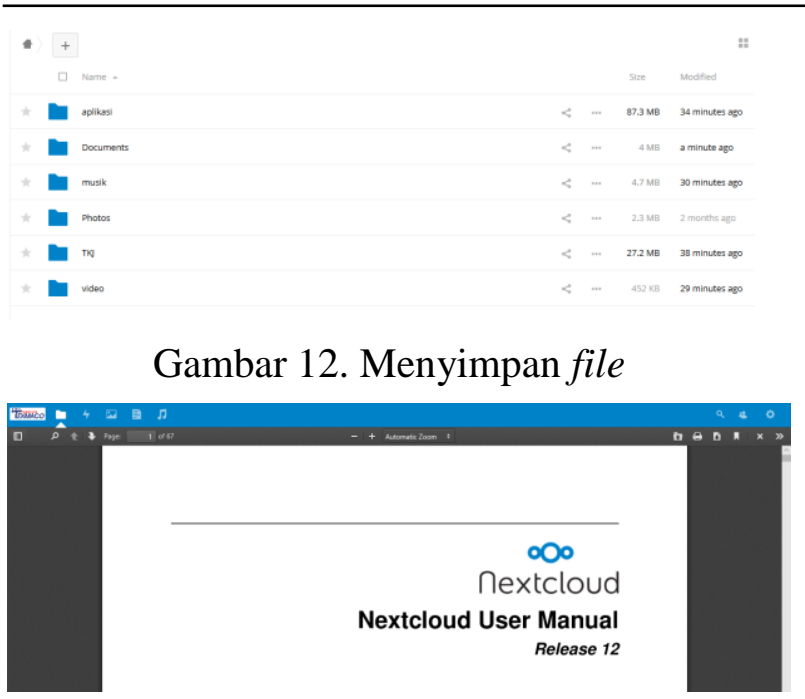

Gambar 13. Membuka file pdf

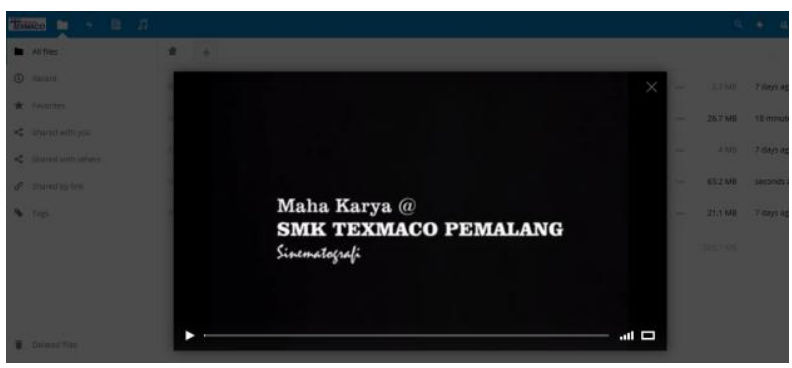

Gambar 14. Membuka file video

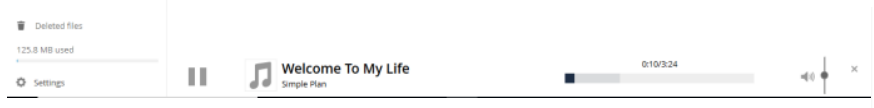

Gambar 15. Membuka file musik

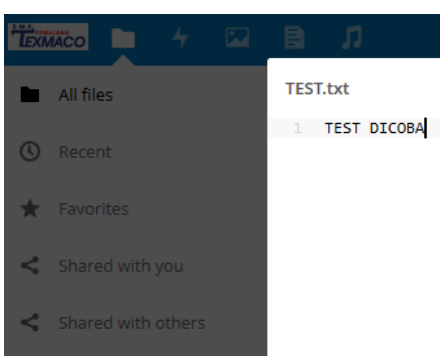

Gambar 16. Membuat file txt

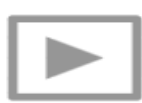

profil smk texmaco pemalang.mp4

\63.2 MB, 2 minutes ago Nags

Activities Comments Sharing Versions

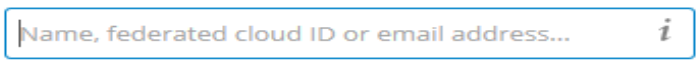

(A) Adi Setiawan

$\checkmark$ Can edit
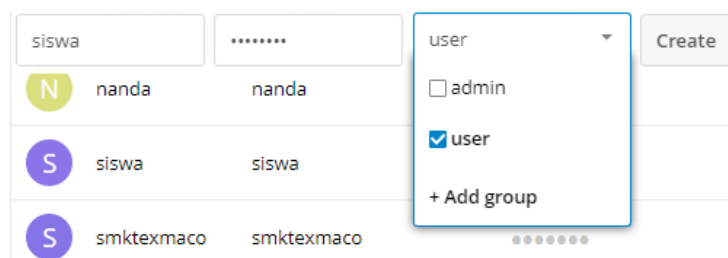

Gambar 18. membuat user

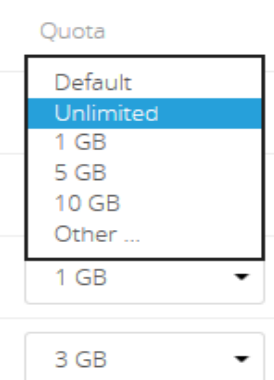

Gambar 19. Memberi kapasitas hardisk

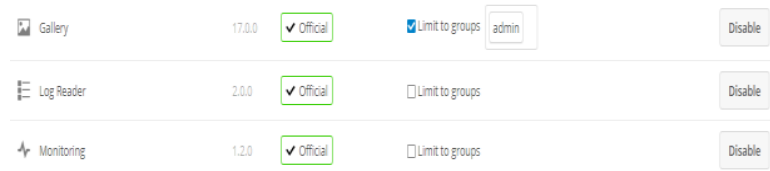

Gambar 20. Memberi limit aplikasi pada user

\begin{tabular}{|c|c|c|c|}
\hline Name & Date modified & Type & Size \\
\hline O. aplikasi & 02-Feb-18 8:59 PM & File folder & \\
\hline C. Documents & 02-Feb-189:50 PM & File folder & \\
\hline Q. musik & 02-Feb-18 9:02 PM & File folder & \\
\hline e. Photos & 02-Feb-18 7:48 PM & File folder & \\
\hline ㅇ. TKJ & 02-Feb-18 9:17 PM & File folder & \\
\hline e. video & 02-Feb-189:50 PM & File folder & \\
\hline 园 02_Simple_Plan-Welcome_To_My_L & 24-Jan-18 9:16 PM & AIMP: MPEG Laye... & $4,768 \mathrm{~KB}$ \\
\hline Nextcloud Manual & 20-Dec-17 4:54 PM & Adobe Acrobat $\mathrm{D}$... & $4,047 \mathrm{~KB}$ \\
\hline test & 24-Jan-18 9:52 PM & Text Document & O KB \\
\hline
\end{tabular}

Gambar 21. synchronizing file

Dari beberapa hasil pengujian yang dilakukan oleh peneliti dan kaprodi teknik jurusan komputer dan jaringan di SMK Texmaco Pemalang bahwa hasil dari rancang bangun cloud storage ini dapat berjalan dengan baik sesuai dengan fungsi fungsinya.

\section{KESIMPULAN}

Dari penelitian ini dapat ditarik kesimpulan dalam mengatasi dokumentasi file sekolah pada SMK Texmaco Pemalang yang masih sering menggunakan media penyimpanan statis berupa flashdisk dan hardisk yang rentan terkena virus, rusak dan hilang. Maka dibuatlah sebuah sistem cloud storage untuk mengatasi masalah tersebut. Dengan 
menggunakan nextcloud sebagai software utama yang dipadukan dengan sistem operasi Linux Ubuntu 16.04, Guru pada SMK Texmaco Pemalang dapat upload,download,sharing file, dan editing file secara online dan tersynchronizing pada PC yang ter integrasi dengan aplikasi nextcloud. Sistem tersebut juga dapat diakses melalui jaringan internet dan local, bagi seorang admin yang ingin meremote dari luar jaringan sekolah bisa dilakukan dengan menggunakan service SSH. Pada sistem yang telah dibuat telah diuji keamanannya menggunakan aplikasi Nmap dan wireshark yang menunjukan bahwa masih terdapat port yang rentan untuk dimasuki oleh seorang hacker, namun masalah tersebut sudah diatasi dengan di installnya paket fail2ban. Hasil tes menunjukan bahwa kecepatan maximal yang diperoleh saat melakukan upload adalah $817 \mathrm{Kbps}$, minimal $80 \mathrm{Kbps}$ dengan average 249 Kbps. Hasil tes download yang diperoleh maximal $180 \mathrm{Kbps}$, minimal $80 \mathrm{Kbps}$, dengan average $130 \mathrm{Kbps}$.

Pada penelitan ini masih terdapat kekurangan yaitu agar selanjutnya sistem cloud storage dapat terintegrasi software editing document server supaya dalam pengolahan file document seperti file doc,ppt,xls dapat dilakukan secara langsung pada sistem tanpa harus mensinkronkan file pada komputer user.

\section{Daftar Pustaka}

[1] Mell, P., \& Grance, T. (2011). The NIST Definition of Cloud Computing Recommendations of the National Institute of Standards and Technology. National Institute of Standards and Technology, Information Technology Laboratory, $800(145), 2$.

[2] Ibrahim, M. \& Kusnawi (2013). Analisis Dan Implementasi Owncloud sebagai media penyimpanan pada Yayasan Salman Al-Farisi Yogyakarta. Jurnal ilmiah Data Manajemen dan Teknologi Informasi (DASI), 14(4), 32 .

[3] Mohan, L., Pandey, R., Bisht, S., \& Paint J. (2017). A Comparative Study of SaaS , PaaS and IaaS in Cloud Computing. International Journal on Emerging Technologies, 8(1), 158-160.

[4] Balbudhe, P. O., \& Balbudhe,. P. O (2013). Cloud Storage Reference Model for Cloud Computing. International Journal of IT, Enggineering and Applied Sciences Research (IJIEASR), 2(3), 8185.

[5] Hashemi, S., M., \& Hanani. A. (2014). Cloud Computing : Use Case \& Various Applications. Journal of Advances Computer Sciences \& Technology, 3(2), 160-168.

[6] Ahmed, M., \& Ashraf H., M. (2014). Cloud Computing and Security Issues in the Cloud. International Journal of Network Security \& Its Applications, 6(1), 25-36

[7] Fauziah, Y. (2014). Tinjauan Keamanan Sistem Pada Teknologi Cloud Computing. Jurnal Informatika, 8(1), $870-883$. 